\title{
日本と途上国の看護技術の差異（中国）
}

\section{— 中国で活動した青年海外協力隊員への面接と報告書の分析}

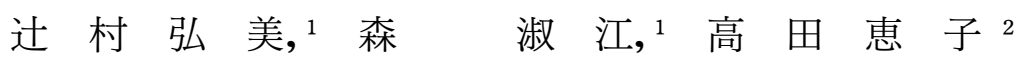 \\ 宮越 幸 代 ${ }^{2}$
}

\begin{abstract}
要旨
【背景・目的】看護は各国の様及な背景や状態により異なると考元られる. 中国で活動した青年海外協力隊 員の面接調査と国際協力機構への報告書を分析し，その差異を明らかにすることで, 国際看護協力における 示唆を得る.【対象と方法】看護師隊員 4 名の報告書計 20 冊と本人への面接結果を対象とし, 日本の看護 と異なる点を抽出した：【結 果】「臨地実習に扔いて学生が行う基本的な看護技術」の 80 項目中, 日本と 異なる看護に関する記述は 41 項目で, 対象者全員が差異があると述べた看護は, 「創傷管理技術」「「与薬の技 術」,「身の回りの援助は家族が行う」,「看護記録」であった. 4 名中 3 名が差異があると述べた看護は, 「膀胱 内留置カテーテル法」,「点滴静脈内注射・中心静脈栄養管理」「手洗い」などであった.【結 論】 日本と中 国の違いが示唆されたので, 中国での看護技術の教育や臨床での状況について把握していく. (Kitakanto Med J $2009 ; 59: 51 \sim 58)$
\end{abstract}

キーワード : 看護技術, 差異, 開発途上国, 中国, 青年海外協力隊

\section{は じめに}

青年海外協力隊は, 開発途上国の要請に応じて, それ らの国々の社会・経済の発展に協力したい人々の活動を 支援する独立行政法人国際協力機構（以下 JICA）の事 業1であるが, 20 歳から 39 歳と年齢も若く, 国際協力を 初めて行うものにとっては, 日本との看護の違いを感じ て戸惑い，疑問を抱いている場合が多い．実際に，青年海 外協力隊の看護職隊員からの技術顧問への質問について 分析した戸塚 ${ }^{2}$ は「隊員からの質問内容には日本の経験 と異なる派遣国の看護技術やケアの違い関する項目が 最も多かった.」と報告している.また, 青年海外協力隊の 体験談や報告書などを見ると，開発途上国の看護やその 技術については, 先進国と比べると劣っており, ネガ ティブに記載されていることも多い.しかしながら, 途 上国で行っている看護やケアの中にも，关の国や地域に 根ざしたものが存在すると考える.

国際看護の定義 3,4 加見ても「国際看護とは, 自分の
ものとは異なる国 (独立国として認定されていない地域 も含む) でその国の社会, 政治, 経済, 教育, 文化, 保健医 療システム, 疾病構造など看護に影響するあらゆるもの を考慮して適応する看護のことである」とあるように， その国の様及な背景や状態によって看護や看護技術には 違いがあると考元られる. 国際協力を初めて行う者に とっては特に, 経験が浅い分, 今までの経験から自分の 国の物差しで, 看護の善し悪しを判断している 場合も多 いのではないかと考元られる。

筆者は, 2001 年 12 月から 2003 年 12 月までの 2 年間, 中国に看護職隊員として派遣された，その活動のなかで 看護学校や病院での看護や看護技術の違いを目の当たり にしていたが，どうしてそうするのかなど根拠まで追求 することはなかった，そこで, 日本と中国との看護の差 異を青年海外協力隊員の報告書と面接調査から明らかに したいと考えた.

1 群馬県前橋市昭和町3-39-15 群馬大学医学部保健学科 2 埼玉県越谷市三野宮820 埼玉県立大学保健医療福祉学部看護学科 平成 20 年 12 月 5 日 受付

論文別刷請求先＝371-8514 群馬県前橋市昭和町3-39-15 群馬大学医学部保健学科＼cjkstart辻村弘美 
研 究 目 的

中国で活動した青年海外協力隊員 (以下 JOCV) の JICA への報告書と JOCV 帰国隊員への面接調査から日 本と異なる看護に関する記述を抽出し, その差異を明ら かにする. 本研究により，その看護の根拠を導き出すこ とができれば，対象国に見合った看護の方向性について の示唆を得ることができると考える.

\section{用語 $の$ 説 明}

\section{青年海外協力隊員が書く JICA への報告書：}

任期中の 2 年間に 1 号報告書から 5 号報告書の 5 回の 報告書の提出が義務づけられている．青年海外協力隊員 は，あらかじめ指定されたフォームに基づき記載する. 各報告書の表紙には，一般公開及び複写の許可の有無を 記入する (表 1$)$.

表 1 JICA への報告書の概要

\begin{tabular}{|l|c|l|}
\hline 報告書 & 提出時期 & \multicolumn{1}{|c|}{ 記載内容 (一部抜粋) } \\
\hline 1 号 & 赴任 3 ケ月目 & $\begin{array}{l}\text { 1. 任国事情 } \\
2 .\end{array}$ \\
\hline 2 配属先の概要
\end{tabular}

研 究 方 法

\section{1. 対象}

2004 年度から 2005 年度末までに中国に看護師として 派遣された青年海外協力隊員 (以下看護師隊員) 4 名が 作成した JICA への報告書計 20 冊の分析と本人への個 人面接を行った.

\section{2. 分析方法}

報告書の分析では,「日本と異なる点」項目に書かれて いる記述を中心に抽出し, 意味が変わらぬよう短文化し, 1 意味 1 文章としデータとした. また帰国後に日本で, 報 告書の内容とその分析結果を参考資料として半構成的面 接を行い, 報告書と同様にデータ化を行った，得られた データを平成 15 年の厚生労働省看護基礎教育における 技術教育のあり方に関する検討会報告書の「臨地実習に おいて学生が行う基本的な看護技術」(表 2)の 13 の大項 目と 80 の小項目に沿って分類した. また, 対象の看護技 術について行われていないと記述されたものに関しても データとした.

\section{3. 倫理的配慮}

報告書は一般公開及び複写が許可されたものを対象と し, 個人面接では, 本研究の目的, 方法などを説明後, 研 究参加同意書への署名後に調査を行った. また, 面接調 査では，デー夕の正確性を確保するために，本人同意を 得て ICレコーダーに録音した。

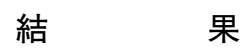

看護師隊員の配属先は病院 3 名, 看護学校 1 名の計 4 名で, 配属先は 2 省 2 自治区の計 4 地域 (表 3) であった.

表 2 「臨地実習において学生が行う基本的な看護技術」

\begin{tabular}{|c|c|}
\hline \multirow[t]{3}{*}{ 1. 環境調整技術 } & 1. 療養生活環境調整 (温・湿度, 換気, 採光など) \\
\hline & 2. ベッドメーキング \\
\hline & 3. リネン交換 (シーツ交換など) \\
\hline \multirow[t]{5}{*}{ 2. 食事援助技術 } & 4. 食事介助 \\
\hline & 5. 経管采養法 (経鼻胃チューブの挿入) \\
\hline & 6. 経管采養法 (流動食の注入) \\
\hline & 7. 栄養状態・体液・電解質バランスの査定 \\
\hline & 8. 食生活支援 \\
\hline \multirow[t]{11}{*}{ 3. 排泄援助技術 } & 9. 自然排尿・排便援助 \\
\hline & 10. 便器 - 尿器の使い方 \\
\hline & 11. 摘便 \\
\hline & 12. 才公ツ交換 \\
\hline & 13. 失禁ケア \\
\hline & 14. 膀胱内留置カテーテル法 (管理) \\
\hline & 15. 膀胱内留置カテーテル法 (カテーテル挿入) \\
\hline & 16. 浣腸 \\
\hline & 17. 導尿 \\
\hline & 18. 排尿困難時の援助 \\
\hline & 19. ストーマ造設者のケア \\
\hline
\end{tabular}




\begin{tabular}{|c|c|}
\hline \multirow[t]{8}{*}{ 4. 活動・休息援助技術 } & 20. 歩行・移動の介助 \\
\hline & 21 . 移送 $($ 車椅子 $)$ \\
\hline & 22. 移送 (ストッレチャー) \\
\hline & 23. 関節可動域訓練 \\
\hline & 24. 廃用性症候群予防 \\
\hline & 25. 体位変換 \\
\hline & 26. 入眠・睡眠の援助 \\
\hline & 27. 安静 \\
\hline \multirow[t]{8}{*}{ 5. 清潔・衣生活援助技術 } & 28. 入浴介助 \\
\hline & 29. 部分浴・陰部ケア \\
\hline & 30 . 清拭・洗髮 \\
\hline & 31. 口腔ケア \\
\hline & 32. 整容 \\
\hline & 33. 寝衣交換など衣生活支援 (臥床患者) \\
\hline & 34. 葠衣交換など衣生活支援 (輸液ライン患者) \\
\hline & 35. 沐浴 \\
\hline \multirow[t]{11}{*}{ 6. 呼吸・循環を整える技術 } & 36. 酸素吸入療法 \\
\hline & 37. 吸引 (口腔, 鼻腔) \\
\hline & 38. 吸引 (気管内) \\
\hline & 39. 酸素ボン心゙の操作 \\
\hline & 40. 気道内加湿法 \\
\hline & 41. 体位ドレナージ \\
\hline & 42. 体温調整 \\
\hline & 43. 低圧胸腔内持続吸引中の患者のケア \\
\hline & 44. 人工呼吸器装着中の患者のケア \\
\hline & 45. 人工呼吸器の操作 \\
\hline & 46. 低圧胸腔内持続吸引器の操作 \\
\hline \multirow[t]{3}{*}{ 7. 創傷管理技術 } & 47. 包帯法 \\
\hline & 48. 創傷処置 \\
\hline & 49. 裖瘡 (予防) ケア \\
\hline \multirow[t]{6}{*}{ 8. 与薬の技術 } & 50. 直腸内与薬方法 \\
\hline & 51. 輸液ポンプの操作 \\
\hline & 52. 経口・経皮・外用薬の与薬方法 \\
\hline & 53. 皮下・皮内・筋肉内・静脈内注射の方法 \\
\hline & 54. 点滴静脈内注射 ・ 中心静脈栄養管理 \\
\hline & 55. 輸血の管理 \\
\hline \multirow[t]{8}{*}{ 9. 救命救急処置技術 } & 56. 救急法 \\
\hline & 57. 意識レベル把握 \\
\hline & 58. 気道確保 \\
\hline & 59.人工呼吸 \\
\hline & 60. 気管内插管 \\
\hline & 61. 閉鎖式心マッサージ \\
\hline & 62. 除細動 \\
\hline & 63. 止血 \\
\hline \multirow[t]{7}{*}{ 10. 症状・生体機能管理技術 } & 64. バイタルサインの観察 \\
\hline & 65. 身体測定 \\
\hline & 66. 症状・病態の観察 \\
\hline & 67. 検体の採取と扱い方 (採尿, 尿検査) \\
\hline & 68. 検体の採取と扱い方 (採血, 血糖測定) \\
\hline & $\begin{array}{l}\text { 69. 経皮的・侵襲的検查時の援助 (心電図モニター・パルスオキシメータの } \\
\text { 使用スパイロー使用) }\end{array}$ \\
\hline & 70. 検査時の援助 (胃カメラ, 気管支鏡, 腰椎穿刺, 12 誘導心電図など) \\
\hline \multirow[t]{3}{*}{ 11. 感染予防の技術 } & 71. スタンダードプリコーション \\
\hline & 72. 無菌・清潔操作 \\
\hline & 73. 医療廃棄物管理 \\
\hline \multirow[t]{4}{*}{ 12. 安全管理技術 } & 74. 療養生活の安全確保 \\
\hline & 75. 転倒・転落・外傷予防 \\
\hline & 76. 医療事故予防 \\
\hline & 77. リスクマネジメント \\
\hline \multirow[t]{3}{*}{ 13. 安全確保の技術 } & 78. 体位保持 \\
\hline & 79. 罨法等身体安楽促進ケア \\
\hline & 80. リラクセーション \\
\hline
\end{tabular}


表 3 対象者の属性

\begin{tabular}{|c|c|c|c|c|}
\hline 対象者 & 配属先 & 病院の規模* & 配属科, 部署 & 配属場所 \\
\hline A & & 国家 2 級乙 & 整形外科・脳外科 & 中国四川省 \\
\hline B & 病 & 国家 2 級甲 & 外科, ICU & 広西チワン族自治区 \\
\hline $\mathrm{C}$ & & 国家 3 級甲 & 外科 (主に消化器) & 湖北省 \\
\hline $\mathrm{D}$ & 衛生学校 & - & 主に基礎看護学 & 新疆ウイグル自治区 \\
\hline
\end{tabular}

*病院は職員の充足度・技術のレベル・病床数・設備の質と量によって等級が付される. 政府直轄の病院 や省の病院はお拉むね最高級の 3 級に, 市立は 2 級, 地元の衛生所や衛生院では 1 級にランク付けされ ることが多い. それぞれの級ははさらに甲・乙・丙に細分される. ${ }^{5}$

表 4 日本と異なる中国の看護に関する分類とその記述例

\begin{tabular}{|c|c|c|}
\hline 大 項 目 & 小 項 目 & 記 \\
\hline 1． 環境調整技術 (2) & $\begin{array}{l}\text { 1. 療養生活環境調整 (2) } \\
\text { (温・湿度, 換気, 採光など) }\end{array}$ & ・カーテンや衝立などがなくプラバシーの配慮がない \\
\hline 2. 食事援助技術 (1) & 4. 食事介助 (1) & ・食事介助はない (学校でも教えていない) \\
\hline \multirow[t]{4}{*}{ 3. 排泄援助技術 (6) } & 12. オムツ交換 (1) & ・新生児はおむつをしない \\
\hline & $\begin{array}{l}\text { 14. 膀胱内留置カテーテル法 (管 } \\
\text { 理) (1) }\end{array}$ & ・朝に尿がでるという理由で朝 4 時にカテーテルを拢 \\
\hline & $\begin{array}{l}\text { 15. 膀胱内留置力テーテル法 (カ } \\
\text { テーテル挿入) (3) }\end{array}$ & $\begin{array}{l}\text { ・固定水は蒸留水ではなく生理食塩水をいれるる゙ } \\
\text { ・カテーテル (外陰部) の消毒はソ用する }\end{array}$ \\
\hline & 16. 浣腸 (1) & ・術前処置で高圧浣腸を行つている \\
\hline \multirow[t]{2}{*}{ 4. 活動・休息援助技術 (2) } & 22. 移送 (ストッレチャー) (1) & ・移動の際に頭が先に移動する \\
\hline & 25. 体位変換 $(1)$ & ・体位変換をせずに円座を使用することが多い \\
\hline \multirow[t]{5}{*}{ 5. 清潔・衣生活援助技術 (5) } & 28. 入浴介助 $(1)$ & ・浴槽に浸かるという習慣はない \\
\hline & 30. 清拭・洗髮 $(1)$ & - 発熱している患者にアルコール清拭をする \\
\hline & 31. 口腔ケア (1) & $\begin{array}{l}\text { ・臥床患者全てに生理食塩水に浸した綿球を使ってロ } \\
\text { 腔ケアを行っていた }\end{array}$ \\
\hline & $\begin{array}{l}\text { 33. 㾛衣交換など衣生活支援 (臥 } \\
\text { 者) }\end{array}$ & ・新生児の衣服はギュッと包む \\
\hline & 35. 沐浴 (1) & ・新生児の沐浴の授業はなく,臨床でどうかは不明 \\
\hline \multirow[t]{3}{*}{ 6. 呼吸・循環を整える技術 (3) } & 36. 酸素吸入療法 (1) & $\begin{array}{l}\text { ・中央配管のない場合は酸素袋にチューブを付けて患 } \\
\text { 者にマスクを付てもらい投与する }\end{array}$ \\
\hline & 37. 吸引 (口腔, 鼻腔) (1) & $\begin{array}{l}\text { ・使った吸引チューブは消毒液に浸けず空の点滴瓶に } \\
\text { 入れ使いまわす }\end{array}$ \\
\hline & 42. 体温調整 (1) & $\begin{array}{l}\text { ・温蔨法担当の着護師がいて指示のもとに漢方液に浸 } \\
\text { したタオルを使って援助する }\end{array}$ \\
\hline \multirow[t]{2}{*}{ 7．創傷管理技術 (5) } & 48． 創傷処置 (1) & $\begin{array}{l}\text { ・処置に使用する摂子立てには蓋があり, その一部に } \\
\text { 穴があいており,そこ摂子を差し込む }\end{array}$ \\
\hline & 49. 裖瘡 (予防) ケア (4) & $\begin{array}{l}\text { ・イソジを使って消毒する } \\
\text { ・温熱療法 (赤外線) で治療する }\end{array}$ \\
\hline \multirow[t]{2}{*}{ 8. 与薬の技術 (7) } & $\begin{array}{l}\text { 53. 皮下・皮内・笳肉内・静脈内 } \\
\text { 注射の方法 }(4)\end{array}$ & $\begin{array}{l}\text { ・筋肉注射は必ず臂部に行う } \\
\text { •筋肉注射で薬液を入れているときに周囲の皮膚を細 } \\
\text { かいリズムで押す }\end{array}$ \\
\hline & $\begin{array}{l}\text { 54. 点滴静脈内注射・中心静脈采 } \\
\text { 養管理 }(3)\end{array}$ & $\begin{array}{l}\text { ・来梢括入はイソジン消毒後, 翼状針を用い手背が第 } \\
\text { 一選択である } \\
\text { ・持続点滴はしない (朝夕点滴をして昼間仕事をする } \\
\text { 人がいる) }\end{array}$ \\
\hline 9. 救命救急処置技術 (1) & 60. 気管内挿管 (1) & •挿管中の患者の頭の下に円座を使用している \\
\hline 10. 症状・生体機能管理技術 (3) & 64. バイタルサインの観察 (3) & 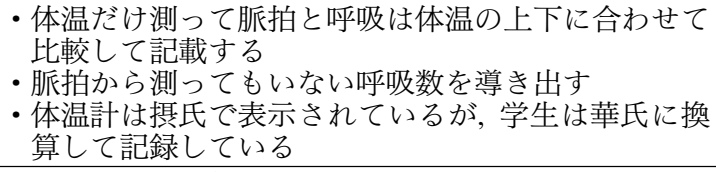 \\
\hline \multirow[t]{3}{*}{ 11. 感染予防の技術 (5) } & $\begin{array}{l}\text { 71. スタンダードプリコーション } \\
\text { (1) }\end{array}$ & $\begin{array}{l}\text { ・患者がいても毎日, すべての部屋を紫外線で } 30 \text { 分消 } \\
\text { 毒する }\end{array}$ \\
\hline & 72. 無囷・清潔操作 $(2)$ & - 滅菌された消毒瓶を再度水道水で洗って使用する \\
\hline & 73. 医療廃棄物管理 (2) & $\begin{array}{l}\text { ・血液のついたガーゼなどは一般のゴミ箱に捨てる } \\
\text { ・使用済み針はそのまま一般ゴミに捨てる }\end{array}$ \\
\hline \multicolumn{3}{|l|}{ 12. 安全管理技術 $(0)$} \\
\hline 13． 安全確保の技術 (1) & 80. リラクセーション (1) & $\begin{array}{l}\text { ・リラクセーションのためにべっ甲の櫛のようなもの } \\
\text { で背中をかく }\end{array}$ \\
\hline \multirow[t]{4}{*}{ その他 (12) } & 身の回りの援助は家族が行う (4) & ・清拭, 移動, 排泄介助, 食事援助などは家族が行う \\
\hline & 看護記録 $(4)$ & $\begin{array}{l}\text { ・アセスメントがないまま評価する } \\
\text { ・体温測定はするが脈拍, 呼吸は測っていない数值を } \\
\text { 記録する }\end{array}$ \\
\hline & 手洗い (3) & ・手洗い後は白衣で手を拭く \\
\hline & $\begin{array}{l}\text { 動脈採血，縫合などは看護師の仕 } \\
\text { 事 (1) }\end{array}$ & ・看護師が動脈採血, 縫合などの処置を行う \\
\hline
\end{tabular}




\section{1. 日本と差異があると述べた看護技術項目 (表 4)}

「臨地実習に抢いて学生が行う基本的な看護技術」の 小項目 80 項目中, 日本と異なる看護技術関する記述 は 41 項目であった. 対象者 4 名全員が, 差異があると述 べた看護技術は,【創傷管理技術 (褯瘔ケア)】,【与薬の技 術 (皮下・皮内・筋肉内・静脈内注射の方法)】，关の他に 分類した【日本では看護師が行う身の回りの援助は家族 が行う】、【看護記録】であった. 4 名中 3 名が差異がある と述べた看護技術は, 【膀胱内留置カテーテル法 (カテー テル挿入)】, 【点滴静脈内注射・中心静脈栄養管理】, 【バイ タルサインの観察】，その他に分類した【手洗い】であっ た. 4 名中 2 名が差異があると述べた看護技術は、【療養 生活環境調整 (温・湿度, 換気, 採光など)】【無菌・清潔 操作】、医療廃棄物管理】であった. 以下に, 上に挙げた 看護技術の項目についてその具体的内容を示す. 4 名中 1 名が差異があると述べた看護技術は，【食事介助】【オ ムツ交換】【膀胱内留置カテーテル法 (管理)】,【浣腸】, 【移送 (ストッレチャー)】、【体位変換】【入浴介助】、清 拭・洗髪】、【腔ヶア】【寝衣交換など衣生活支援 (臥床 患者)】、【沐浴】、酸素吸入療法】【吸引(口腔, 鼻腔)】,【体 温調整】【創傷処置】【気管内挿管】【スタンダードプリ コーション】,【リラクセーション】，その他に分類した 【動脈採血, 縫合などは看護師の仕事】であった。

\section{1 ）「臨地実習において学生が行う基本的な看護技術」 の小項目からの分類}

\section{(1) 対象者 4 名全員が差異があると述べた看護技術} 項目

【創傷管理技術 (褾瘡ケア)】では「裖瘡の処置はイソ ジンを使って消毒する」,「裖㾅を温熱療法で治療する」, 【与薬の技術 (皮下 ・ 皮内 ・筋肉内 ・ 静脈内注射の方法)】 では「筋肉注射は必ず臂部に行う」,「筋肉注射で薬液を 入れているときに周囲の皮膚を細かいリズムで押す」, また，【日本では看護師が行う身の回りの援助は家族が 行う】の身の回りとは, 清拭, 移動, 排泄介助, 食事援助 などであった【看護記録】では「アセスメントがないま ま評価する」,「体温測定はするが脈拍と呼吸は測ってい ない数值を記録する」などであった。

（2）４名中 3 名が差異があると述べた看護技術項目

【膀胱内留置カテーテル法 (カテーテル捚入)】では, 「固定水は蒸留水でなくて生理食塩水をいれる」,「力 テーテル (外陰部) の消毒はイソジンを使用する」,【点滴 静脈内注射・中心静脈栄養管理】では,「末梢挿入はイソ ジン消毒後，翼状針を用い手背が第一選択である」，「注 射の時の消毒は 2 度行っていた」【バイタルサインの観 察】では,「体温だけ測って脈拍と呼吸は体温の上下に合
わせて比較して記載する」,「脈拍から測ってもいない呼 吸数を導き出す」,「体温計は摂氏で表示されているが, 学生は華氏に換算して記録している」【手洗い】では, 「手洗い後は白衣で手を拭く」などであった．

\section{（3）４名中 2 名が差異があると述べた看護技術項目}

【療養生活環境調整 (温・湿度, 換気, 採光など)】では, 「カーテンや衝立などがなくプラバシーの配慮がない」, 「プライバシーが全くない」,【無菌・清潔操作】では,「滅 菌された消毒瓶を再度水道水で洗って使用する」, 【医療 廃棄物管理】では,「血液のついたガーゼなどは一般のゴ ミ箱に捨てる」,「使用済み針はそのまま一般ゴミに捨て る」という内容であった。

（4）４名中 1 名が差異があると述べた看護技術項目

【食事介助】では,「食事介助はない (学校でも教えて いない)」、【オムツ交換】では,「新生児はオムツをしない のでおむつ交換はない」、膀胱内留置カテーテル法（管 理)】では, 「朝に尿がでるという理由で朝 4 時にカテーテ ルを抜く」、【浣腸】では，「術前処置で高圧浣腸を行って いる」, 【移送 (ストッレチャー)】では, 「移動の際に頭が 先に移動する」，【体位変換】では，「体位変換をせずに円 座を使用することが多い」、入浴介助】では，「浴槽に浸 かるという習慣はない」、【清拭・洗髪】では，「発熱して いる患者にアルコール清拭をする」、【腔ケア】では, 「臥床患者全てに生理食塩水に浸した綿球を使って口腔 ケアを行っていた」，【寝衣交換など衣生活支援（臥床患 者)】では,「新生児の衣服はギュッと包む」，【沐浴】では， 「新生児の沐浴の授業はなく, 臨床でぞうかは不明」、酸 素吸入療法】では,「中央配管のない場合は酸素袋に チューブを付けて患者にマスクを付けてもらい投与す る」、【吸引 (口腔, 鼻腔)】では,「使った吸引チューブは 消毒液に浸けず空の点滴瓶に入れ使いまわす」,【体温調 整】では,「温罨法担当の看護師がいて指示のもとに漢方 液に浸した夕オルを使って援助する」、【創傷処置】では, 「処置に使用する摂子立てには蓋があり，その一部に穴 があいており，そこに摂子を差し込む」、【気管内挿管】で は,「挿管中の患者の頭の下に円座を使用している」,【ス タンダードプリコーション】では，「患者がいても毎日， すべての部屋を紫外線で 30 分消毒する」,【リラクセー ション】では,「リラクセーションのためにべっ甲の櫛の ようなもので背中をかく」, その他に分類した【動脈採血, 縫合などは看護師の仕事】では「看護師が動脈採血, 縫合 などの処置を行う」であった。

\section{2 ）「臨地実習において学生が行う基本的な看護技術」 の大項目からの分類}

大項目別に見てみると, 記述が多い順に, 与薬の技術 (7 小項目), 排泄援助技術 (6 小項目), 清潔・衣生活 援助 
技術 (5 小項目), 創傷管理技術 (5 小項目), 感染予防の技 術 (5 小項目), 呼吸・循環を整える技術 ( 3 小項目), 症状・ 生体機能管理技術 ( 3 小項目), 環境調整技術 ( 2 小項目), 活動・休息援助技術 (2 小項目), 食事援助技術 ( 1 小項目), 救命救急処置技術 (1 小項目), 安全確保の技術 (1 小項 目)でそその他として分類したものは記述が多い順に，身 の回りの援助は家族が行う (4 記述), 看護記録 (4 記述), 手洗い (3 記述), 動脈採血, 縫合などは看護師の仕事 (1 記述) であった。この中で, 環境調整技術 ( 2 小項目), 食事 援助技術 ( 1 小項目), 排泄援助技術 ( 1 小項目), 清潔・衣 生活 援助技術 (1 小項目) については, これらの技術につ いて行われていないという内容で, 具体的には,「カーテ ンや衝立などがなくプラバシーの配慮がない」,「食事介 助はない (学校でも教えていない)」「新生児はおむつを しない」,「新生児の沐浴の授業はなく, 臨床で行ってい るか不明である」であった.また, 安全管理技術について は看護の差異について述べられていなかった。

\section{考察}

\section{1. 日本と差異があると述べた特徴な看護技術項目}

1 )【与薬の技術（筋肉内注射の方法）】について

「筋肉注射は必ず慰部に行う」について,中国の基礎看 護学の教科書 7,8 を見てみると, 筋肉注射部位に関して 「筋肉注射は一般に筋肉の比較的厚いところ，なおかつ 血管や神経を外す，その中でもっとも選択されている注 射部位は大臂筋, その次に中慰筋, 小臂筋, 外股の筋肉扔 よび上腕三角筋である.」と記されている.このことから 教育現場では, 筋肉注射部位の第一選択は㯏部で指導し ていることが考えられる.

\section{2 )【点滴静脈内注射】について}

「末梢挿入はイソジン消毒後, 翼状針を用い手背が第 一選択である」,「注射の時の消毒は 2 度行っていた」に ついては, 筆者自身の中国での看護師隊員としての経験 からも，同じ状況であった，中国の基礎看護学の教科 書9,10を見てみると, 未梢の挿入部位は, 手背だけでなく その他の四肢の静脈について示されていたものの, 教科 書の末梢の挿入の写真については手背が載せられてい た. 一方, 挿入部位の消毒についてはヨード液で 2 回消 毒すると書かれており,これは調査結果と同じであった.

\section{2. 文化の違いから考えられる看護の差異}

異国での看護について考えるときに，異文化看護の視 点は欠かす事ができない. 異文化看護とは, 看護の視点 に文化の概念を取り込み，あらゆる場面で人間の生活と は切り離せない文化を考慮して行う看護である. ${ }^{11}$ 中国 では看護師の主な業務は, 医師の指示による点滴や静脈 注射などの医療行為と診療補助であり, 入院患者の介護
は家族・親族や付き添い婦が行うのが慣例となってい る. ${ }^{6}$ また, 中国の看護師の業務を規定している法律であ る「中華人民共和国護士管理方法」では, その業務を「医 師の指示を遂行」, 「患者の心身状態の観察とケアの提 供」,「保健・健康指導と患者教育」と規定している. ${ }^{12}$ 結 果と比較してみると, その他に分類された【動脈採血, 縫 合などは看護師の仕事】は, まさに医療行為であり,また, 与薬の技術である【与薬の技術 (皮下・皮内・筋肉内 ・ 静 脈内注射の方法)】や【点滴静脈内注射・中心静脈栄養管 理】は記述が多く, 差異が実際にみられたことはもちろ んであるが, 日久の業務の中でこれらの業務の占める割 合が大きく, 日本人看護師がこれらの場面を目につくこ とが多かったことも記述が多い原因だと考元られる。ま た，その他に分類された【日本では看護師が行う身の回 りの援助は家族が行う】記述も, 日本では, 清拭, 移動, 排 泄介助, 食事援助などの身の回りの援助が看護師の主な 業務となっており中国とは期待されている役割が大きく 異なっていることが言える. 環境調整技術, 食事援助技 術については, 行われていないという記述で, また, 安全 管理技術については看護の差異について述べられていな いのは, 中国では身の回りの援助は家族が行うのが一般 的であり，看護師がやっていないことが原因と考える.

【手洗い】の記述が多かった理由は, 看護業務の中で手 洗いの行為が多く, 人目につきやすく, また, 日本人が衛 生的な意識が高いという国民性による影響とも考えられ る.「新生児の衣服はギュッと包む」という記述について は, 中国, フィリピン, ラオスなど多くの国で見られる光 景であるが, その理由については, 保温のため, 安全のた め, 隣の子を引つ搔かないためなど様及であり真相はよ くわからない状況である. ${ }^{11}$

「温罨法担当の看護師がいて指示のもとに漢方液に浸 したタオルを使って援助する」や「リラクセーションの ためにべっ甲の櫛のようなもので背中をかく」という記 述については, 中国人の文化が, 薬草治療や民間療法 (銊

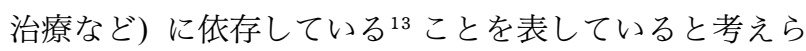
れる。

\section{3. 経済状況の違いから考えられる看護の差異}

開発途上国では, 先進国である日本と違い, 具合が悪 くても何かあればすぐ受診したり, 医療施設や医療物品 などに資金を多く費やすことができない，中国において は，公費医療保険制度はあるが，中国の約 8 割を占める 農民の農村組合医療の加入率は約一割で，まだ，十分に 普及しておらず, ${ }^{6}$ 大きな病気でないと受診しないのが現 状である. 特に今回, 対象とした地域は北京や上海と いった大都市でなく, 地方の中都市の中核病院が多い 結果の【酸素吸入療法】では,「中央配管のない場合は酸 
素袋にチューブを付けて患者にマスクを付けてもらい投 与する」とあるように，医療施設が十分でない場合には コストがかからないもので代用するしかないのが現状で ある．また，【医療廃棄物管理】の「血液のついたガーゼ などは一般のゴミ箱に捨てる」，「使用済み針はそのまま 一般ゴミに捨てる」については，感染に対しての意識が 低いことは否めないものの, それ以上に, 感染物に対し て処理施設やそれに関係する物品や人員などを整備して いくのは簡単でないことが考えられる.【手洗い】に関し ても, 日本のように手洗い後のペーパータオルを常備し ている医療施設は少なく，また，ハンカチなどを持ち歩 く習慣などもないために，白衣で手を拭くというような 習慣になったことが考えられる。

\section{結語}

今回の調査では, 面接と報告書分析により結果に挙げ た日本と中国の違いが示唆された. 今後は, 現地で使わ れている教科書の内容を把握するとともに看護技術の教 育の現状や臨床での状況などについて調査を進めていく ことが課題である.

また，本研究は中国の限られた地域を対象としており， 本研究の結果が一般的な中国の看護の状況ではないこと を申し添える。

本研究は日本学術振興会による平成 19-21 年度科学 研究費補助金 (基盤研究 (C) 課題番号 19592429) の助成 を受けて行ったもので, この研究の一部は 2008 年の国 際看護研究会第 11 回学術集会で発表した.

\section{文献}

1. 國井 修. 国際保健医療のお仕事. 中村安秀 (編). 東京; 南山堂, $2005: 23-45$.

2. 戸塚規子. 開発途上国で保健医療協力に携わる看護職の 活動上の問題一青年海外協力隊員の求める技術支援の分 析から一。第 19 回国際協力学術奨励研究報告書. 1997 : 39-42.

3. 小早川隆敏. 国際保健医療協力入門. 独立行政法人国際協 力機構 (監修). 東京: 国際協力出版会 2006 : 267-272.

4. 森 淑江. 国際看護の概念と看護の国際協力に関する日 本の現状. 看護教育 1997 ; 38(12)：1027-1031.

5. 平井きよ子. 中国の看護事情を見てみたい 1一病院の機 能と看護師の役割. 看護管理 $2003 ； 13(5) ： 386-391$.

6. 坂上皖庸. グローバリゼーションと看護, 最近の中国の医 療事情と衛生状況. Nurse eye 2004；17(4)：25-40.

7. 姜安丽: 新编护理学基础: 第 17 章给药. 北京: 高等教育 出版社, 1999: 380-384.

8. 陶丽云：护理基本技术：第 13 章注射技术. 北京: 高等教 育出版社, 2004：201-206.

9. 姜安丽: 新编护理学基础: 第 18 章静脉输液与输血. 北 京: 高等教育出版社, 1999: 407-411.

10. 陶丽云：护理基本技术：第 15 章 静脉输液法. 北京: 高 等教育出版社, $2004: 231-238$.

11. 戸塚規子：III. 方法論 (基本編). 国際看護学入門. 国際看 護研究会 (編). 東京: 医学書院, 1999：118-123.

12. 謝海棠. 中国における看護教育および看護管理. 日中医学 $2004 ; 18(6)$ : 32-37.

13. Leininger MM. 文化を超えたケアの構成要素のリスト. 稲岡文昭 (監訳)。レイニンガー看護論, 東京：医学書院, 2006 : 190-207. 


\title{
Differences of Nursing between Japan and China :
}

\author{
Analysis of Interviews and Reports by Japan \\ Overseas Cooperation Volunteers working in China \\ Hiromi Tsujimura, ${ }^{1}$ Yoshie Mori, ${ }^{1}$ Keiko Takada ${ }^{2}$ \\ and Sachiyo Miyakoshi ${ }^{2}$ \\ 1 Department of Health Science, Faculty of Medicine, Gunma University \\ 2 Department of Nursing, School of Health and Social Services, Saitama Prefectural University
}

Background and objectives : Nursing practices vary from one country as clarified by an analysis of reports and interviews by Japan Overseas Cooperation Volunteers working in China. We extracted and clarified descriptions of nursing, that differed from those in Japan. Subjects and Methods: We analyzed reports by four nurses and interview results. The differences in nursing between two countries were extracted, according to twenty. Results : We found that 41 of 80 items on basic nursing skills differed in Chinese nursing practice from Japan. Differences indicated by all four nurses involved "wound management technology", "technology of medication", "family assistance", and "nursing records". Nursing differences between the two countries indicated by 3 of the 4 nurses were "technology of bladder catheter", and "injection and central veins of liver nutrition management", and "handwashing". Conclusion : The study clarified some differences in nursing between Japan and China. Therefor, we should conduct a research on recent educational status and clinical setting in China. (Kitakanto Med J 2009; 59:51 58)

Key words: technique, difference, developing countries, China, Japan Overseas Cooperation Volunteer 